\title{
Photocatalytic decolorization of Procion 032 Carmine Red using titania nanotubes
}

\author{
Nguyen Thi Thuy, Huynh Tuan Anh, Ngo Vinh An, and Nguyen Nhat Huy
}

\begin{abstract}
In this study, we report for the first time on the photocatalytic decolorization of Procion 032 Carmine Red (PC032) using titania nanotubes (TNTs). Photocatalysts of TNTs were synthesized by hydrothermal method under strong alkali condition using powder $\mathrm{TiO}_{2}$ as a precursor and calcined at different temperatures $\left(100-7^{\circ} 0^{\circ} \mathrm{C}\right)$. The materials were then characterized by transmission electron microscopy (TEM), Brunauer-Emmett-Teller analysis (BET), and X-ray diffraction (XRD). The decolorization tests of $\mathrm{PC032}$ and other dyes were conducted under ultraviolet at $365 \mathrm{~nm}$ (UVA) irradiation using a batch photocatalytic reactor in which TNTs was suspended in the dye solution by continuous magnetic mixing. Experimental results showed that calcination temperature affected on both the material properties and the photocatalytic activity. The surface area of the materials decreased while anatase crystallinity increased with the increase of calcination temperature, as from BET and XRD results. For photocatalytic activity, TNT calcined at $600^{\circ} \mathrm{C}$ (T-600) showed the highest PC032 removal efficiency of almost $100 \%$ after $60 \mathrm{~min}$ of irradiation. The durability test showed that the activity of T-600 was still stable after at least 10 times of repetition of treatment. Moreover, T-600 was also effective for decolorization of other dyes and could be a promising photocatalyst for advanced wastewater treatment in textile industry.
\end{abstract}

Manuscript Received on March 15 ${ }^{\text {th }}$, 2017, Manuscript Revised on November 01 ${ }^{\text {st }}$, 2017.

This study is funded by CARE-Rescif initiative, Ho Chi Minh City University of Technology, VNU-HCM, under grant number Tc-MTTN-2016-03.

Nguyen Thi Thuy, Ho Chi Minh City University of Food Industry, 140 Le Trong Tan, Tan Phu District, Ho Chi Minh City, Vietnam.

Huynh Tuan Anh, Ho Chi Minh City University of Technology, VNU-HCM.

Ngo Vinh An, Ho Chi Minh City University of Technology, VNU-HCM.

Nguyen Nhat Huy, Ho Chi Minh City University of Technology, VNU-HCM, 268 Ly Thuong Kiet, District 10, Ho Chi Minh City, Vietnam (e-mail: nnhuy@hcmut.edu.vn).
Index Terms-TNTs, Procion 032 Carmine Red, hydrothermal, textile wastewater, photocatalytic wastewater treatment

\section{INTRODUCTION}

$\mathrm{T}$ itania nanotubes (TNTs) have attracted considerable attention because of its tubular structure with high surface area and high activity [1-4]. For TNTs synthesis, hydrothermal method is a widely chosen method due to its simplicity in process and equipment requirement as well as cost-effectiveness, low energy consumption, mild reaction condition, and availability for large-scale production [5]. Although TNTs have been studied for many applications and seem to be a promising photocatalyst [6-8], there has not been any report on the use of TNTs for Procion 032 Carmine Red (PC032) photocatalytic removal.

This study is aimed to prepare TNTs and apply them for photocatalytic decolorization of PC032 as well as some other industrial dyes which are available in Vietnam.

\section{MATERIAL AND METHOD}

TNTs was prepared by hydrothermal alkali method $[9,10]$. $\mathrm{TiO}_{2}$ precursors (Degussa P25, Merck, Germany) were mixed and sonicated with $180 \mathrm{ml}$ of $10 \mathrm{~N} \mathrm{NaOH}$ solution followed by hydrothermal treatment at $135^{\circ} \mathrm{C}$ in a $200 \mathrm{ml}$ autoclave. After cooling down to room temperature, the produced slurry was filtered with $1 \mathrm{~L}$ of deionized (DI) water and sonicated in $1 \mathrm{~L}$ of $\mathrm{HNO}_{3}$ solution for $30 \mathrm{~min}$ at $\mathrm{pH} 1.6$ [11]. The suspension was then filtered and washed with DI water several times until the rinsed $\mathrm{pH}$ reached 6.5 $\sim 7.0$. The material was subsequently dried for $12 \mathrm{~h}$ at $100^{\circ} \mathrm{C}$. Finally, it was calcined at different temperature from $200-$ to $700{ }^{\circ} \mathrm{C}$ for $2.5 \mathrm{~h}$. The products were then named as $\mathrm{T}-\mathrm{x}$, where $\mathrm{x}$ was the calcination temperature. The microstructure of these material was characterized by different techniques such as BET (Brunauer-Emmett- 
Teller), TEM (Transmission Electron Microscopy), and X-ray diffraction (XRD) as mentioned in [9].

Different types of synthetic wastewater with the color of 178-181 Pt-Co were prepared by mixing the powder of PC032 and other industrial dyes (with color of red, orange, yellow, purple, green, and blue) with DI water. Two liters of the wastewater was poured into a $2.5 \mathrm{~L}$ reactor and mixed by a magnetic stirrer. This reactor was covered by an aluminum box to block the spreading of the UV irradiation. An amount of 0.1 $\mathrm{g}$ of photocatalyst was then added and decolorization reaction was conducted for $60 \mathrm{~min}$ either with or without UVA irradiation from an 8 W UVA lamb (highest intensity at $365 \mathrm{~nm}$ ). After $0,5,15,30,45$, and $60 \mathrm{~min}$ of experiment, samples of treated water were collected and centrifuged at $6000 \mathrm{rpm}$ for $12 \mathrm{~min}$. The color of the supernatants was then measured by an UV-vis spectroscopy (DR 5000) at wavelength of $455 \mathrm{~nm}$ (Method 2120 C. Spectrophotometric - SingleWavelength [12]). The color removal efficiency was calculated as following

$$
\eta=\left(1-\frac{C_{\text {out }}}{C_{\text {in }}}\right) \times 100 \%
$$

Where $\mathrm{C}_{\mathrm{in}}$ and $\mathrm{C}_{\text {out }}$ are the color $(\mathrm{Pt}-\mathrm{Co})$ at the beginning and after treatment at certain time, respectively.

\section{RESULTS AND DISCUSSION}

\subsection{Material Preparation and Characterization}

The TEM results of P25 and TNTs materials are displayed in Fig. 1. Results showed that T-100 had tubular shape, which was also the morphology of T-200 and T-300. Besides, TNTs calcined at temperature $\geq 400^{\circ} \mathrm{C}$ lost their tubular structures, which transforms to rod, large particle, and clusters. The BET surface area of TNTs material is illustrated in Table 1. It can be seen that the surface area decreased with the calcination temperature. This may be due to the change in the tube structure of the TNTs material to become larger rods and particles [13-23]. The crystalline structure of P25 and TNTs material is demonstrated in Fig. 2. One can observe that TNTs had only anatase structure. And the crystallinity of TNTs increased with the increase of calcination temperature [13-16, 18-28].

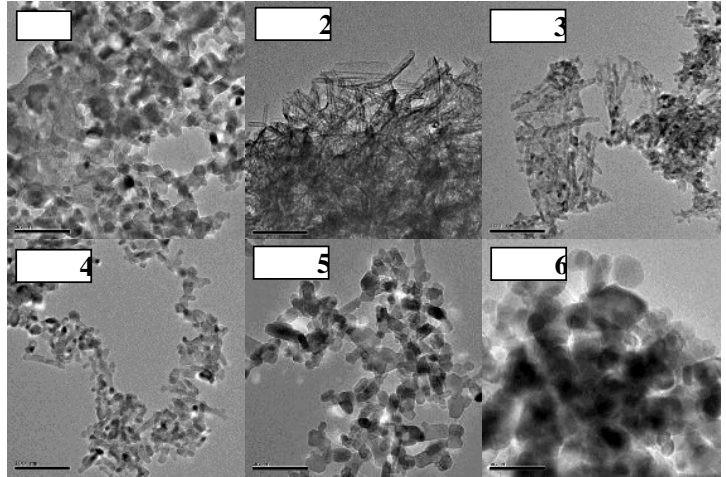

Fig. 1. TEM results of P25 and TNTs (all the scales are 100 $\mathrm{nm})$

TABLE 1

SURFACE AREA AND MORPHOLOGY OF TNTS

\begin{tabular}{lcl}
\hline \hline Sample & $\begin{array}{c}\text { Surface area } \\
\left(\mathbf{m}^{2} / \mathbf{g}\right)\end{array}$ & Morphology \\
\hline P25 & 53 & particle \\
T-100 & 390 & tube \\
T-400 & 161 & tube + rod \\
T-500 & 106 & rod \\
T-600 & 61 & rod + particle \\
T-700 & 26 & large particle \\
\hline \hline
\end{tabular}

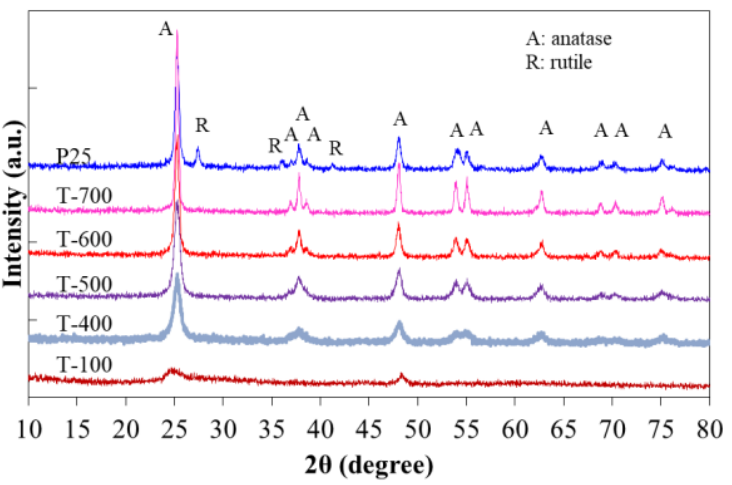

Fig. 2. XRD results of P25 and TNTs calcined at various temperatures

\subsection{Photocatalytic Decolorization}

\subsubsection{Effect of calcination temperature}

The results of decolorization of PC032 using TNTs under UVA irradiation is presented in Fig. 3. It can be seen that the color removal efficiency significantly increased when the temperature increased and reached the highest efficiency at the calcination temperature of $600^{\circ} \mathrm{C}$. In this case, the color was removed to under detection. However, the increase of temperature from 600 to $700^{\circ} \mathrm{C}$ led to an obvious reduction in the color degradation of the photocatalyst. All photocatalysts were further 
applied to treat the synthetic wastewater of red industrial dye. Similar trend of effect of calcination temperature on color removal efficiency was recorded. The highest color efficiency of $71.42 \%$ was again achieved using TNT calcined at $600^{\circ} \mathrm{C}$.

The increase of color removal efficiency of TNTs calcined from 200 to $600^{\circ} \mathrm{C}$ would be explained by the increase of the material crystallinity. However, calcination at the higher temperature would reduce the surface area of TNTs, which resulted in the reduction of photocatalytic activity. Therefore, we selected TNTs calcined at $600^{\circ} \mathrm{C}(\mathrm{T}-600)$ as photocatalyst for all next experiments.

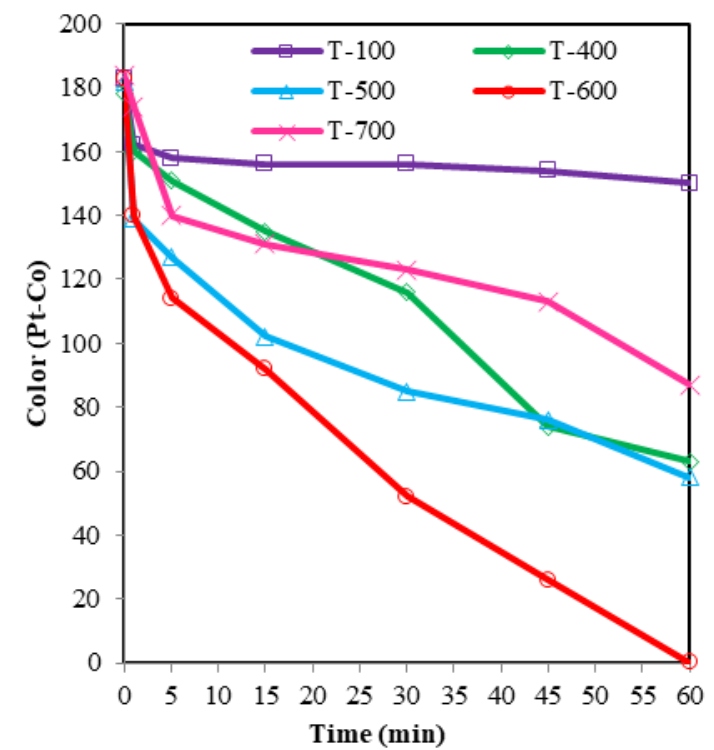

Fig. 3. Decolorization of PC032 solution by different TNTs within $60 \mathrm{~min}$

It is further noted that the similar photocatalysts have been used for $\mathrm{NO}$ and $\mathrm{NO}_{2}$ removal in gaseous phase, as presented in [9]. The results from that report slightly differed from this study since the highest photocatalytic activity was obtained by TNTs calcined at $500^{\circ} \mathrm{C}$. This difference caused by applying in two different phases and target pollutants provides us a more comprehensive view about the behavior of our photocatalysts.

\subsubsection{Effect of UVA irradiation}

The decolorization of PC032 using T-600 was performed without UVA irradiation and the result is showed in Fig. 4. Clearly, the color of PC032 solution only reduced slightly at the beginning then remained unchanged because the photocatalytic reaction could not happen without irradiation. The slight reduction of color observed was due to the adsorption of color on TNT surface.

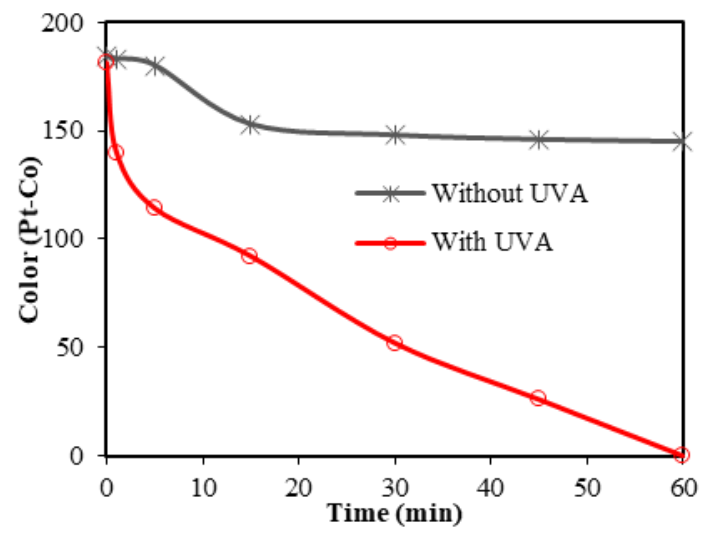

Fig. 4. Effect of UVA irradiation

\subsubsection{Comparison of color removal between T-600 and P25}

Fig. 5 illustrates the color removals of PC032 solution by using T-600 and P25. As can be seen, T-600 removed $100 \%$ color after 60 min white P25 required $30 \mathrm{~min}$ more to achieve this efficiency. Since this is not a significant improvement, future work should be focused on the improvement of TNTs property as well as the experimental condition.

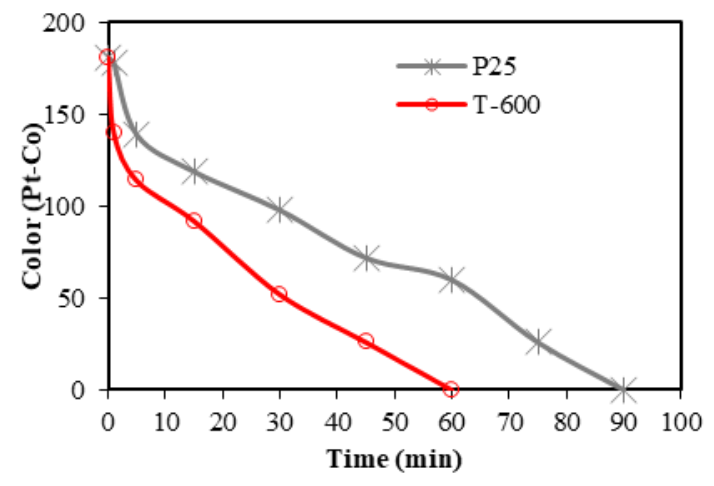

Fig. 5. Decolorization of PC032 solution by T-600 and P25

\subsubsection{Photocatalytic activity of T-600 for long- term experiment}

In this section, the decolorization experiment of PC032 by T-600 was repeated for ten times, each time of $60 \mathrm{~min}$. As can be seen from Fig. 6, color was totally removed for the first four times. Though the removal efficiency wa then gradually reduced, the color of effluent from the $10^{\text {th }}$ time (47 Pt-Co) still met the National Standard. This would show the ability of photocatalyst to provide long-term activity of decolorization. 


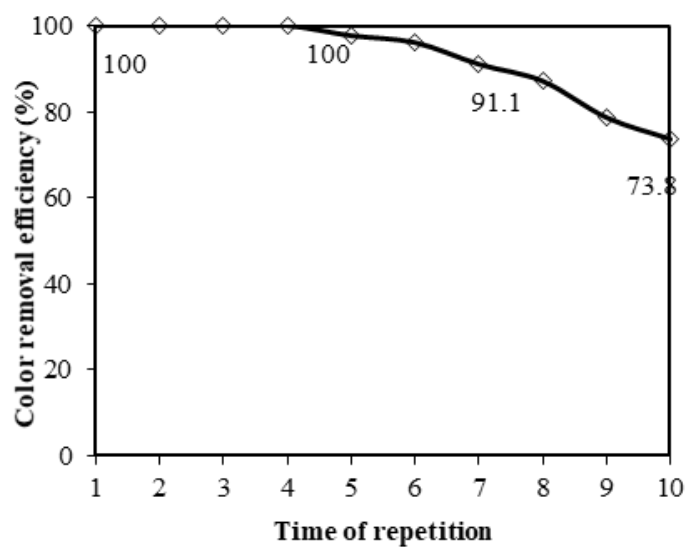

Fig. 6. Decolorization by T-600 from repeated experiments

\subsubsection{Application of T-600 for different types of industrial dye wastewater}

To broaden the application of T-600, we further tested the photocatalytic activity of this catalyst on the solutions of different industrial dyes. As can be seen from Fig. 7, T-600 provided good color removal efficiencies for all dye solutions and most of the effluents met the National Standard, QCVN 13-MT:2015/BTNMT, column A (<75 Pt-Co). However, these efficiencies were lower than the efficiency obtained from PC032 solution, suggesting that decolorization partially depends on the nature of the dyes. Further studies on photocatalytic mechanism are needed to enhance removal efficiency for industrial dyes solution.

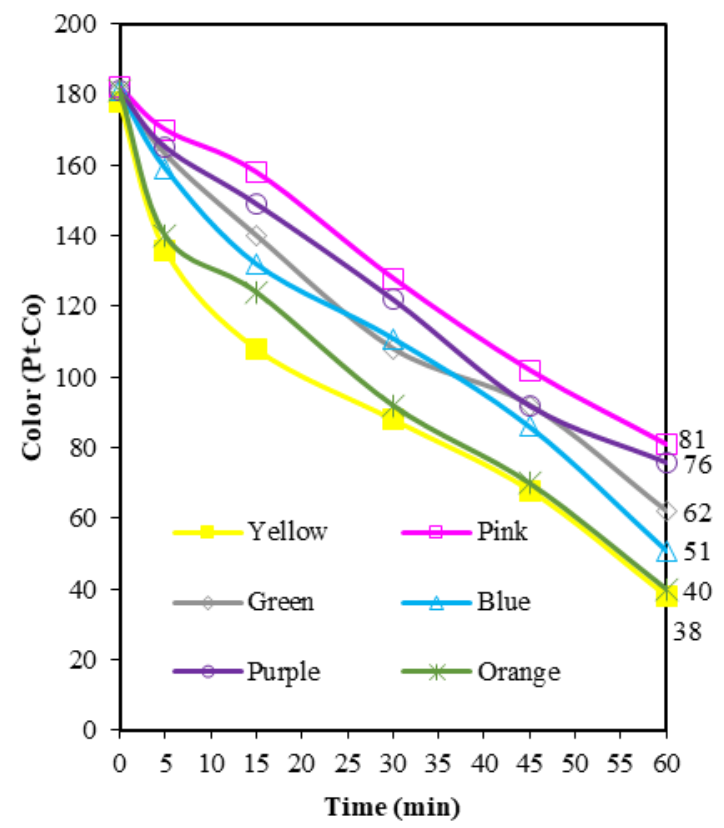

Fig. 7. Decolorization by T-600 for various types of wastewater

\section{CONCLUSIONS}

TNT photocatalysts were synthesized and their photocatalytic activity was tested for decolorization of the solutions of PC032 and several industrial dyes. Calcination temperature showed significant effects on color removal efficiency of $\mathrm{PC} 032$ and red industrial dye, where TNTs calcined at $600^{\circ} \mathrm{C}$ (T-600) showed the highest removal efficiency. Compared to P25, T600 provided a faster color removal of PC032 solution and the major removal mechanism was photocatalysis. In addition, this photocatalyst showed the good photocatalytic activity for at least 10 times of repetition of dye treatment. Different color removal efficiencies were achieved when $\mathrm{T}$ 600 was applied to treat the industrial dye solutions with different colors. Although the effluents after the treatment mostly met the National Standard (QCVN 13-MT: 2015/BTNMT, column A), further investigation of photocatalytic mechanism and the products from the reaction should be addressed.

\section{REFERENCES}

[1] M. Ge, C. Cao, J. Huang, S. Li, Z. Chen, K.-Q. Zhang, et al., "A review of one-dimensional $\mathrm{TiO} 2$ nanostructured materials for environmental and energy applications," Journal of Materials Chemistry A, 2016.

[2] N. Liu, X. Chen, J. Zhang, and J. W. Schwank, "A review on $\mathrm{TiO}_{2}$-based nanotubes synthesized via hydrothermal method: Formation mechanism, structure modification, and photocatalytic applications," Catalysis Today, vol. 225, pp. 34-51, 4/15/ 2014.

[3] P. Roy, S. Berger, and P. Schmuki, "TiO2 Nanotubes: Synthesis and Applications," Angewandte Chemie International Edition, vol. 50, pp. 2904-2939, 2011.

[4] T. Sekino, "Synthesis and Applications of Titanium Oxide Nanotubes," in Inorganic and Metallic Nanotubular Materials. vol. 117, T. Kijima, Ed., ed: Springer Berlin Heidelberg, 2010, pp. 17-32.

[5] Y. Guo, N.-H. Lee, H.-J. Oh, C.-R. Yoon, K.-S. Park, W.$\mathrm{H}$. Lee, et al., "Preparation of titanate nanotube thin film using hydrothermal method," Thin Solid Films, vol. 516, pp. 8363-8371, 2008.

[6] H. H. Ou and S. L. Lo, "Review of titania nanotubes synthesized via the hydrothermal treatment: Fabrication, modification, and application," Separation and Purification Technology, vol. 58, pp. 179-191, Dec 12007.

[7] C. L. Wong, Y. N. Tan, and A. R. Mohamed, "A review on the formation of titania nanotube photocatalysts by hydrothermal treatment," Journal of Environmental Management, vol. 92, pp. 1669-1680, Jul 2011.

[8] D. V. Bavykin, J. M. Friedrich, and F. C. Walsh, "Protonated Titanates and $\mathrm{TiO}_{2}$ Nanostructured Materials: Synthesis, Properties, and Applications," Advanced Materials, vol. 18, pp. 2807-2824, 2006.

[9] N. H. Nguyen and H. Bai, "Photocatalytic removal of NO and $\mathrm{NO}_{2}$ using titania nanotubes synthesized by 
hydrothermal method," Journal of Environmental Sciences, vol. 26, pp. 1180-1187, 5// 2014.

[10] T. Kasuga, M. Hiramatsu, A. Hoson, T. Sekino, and K. Niihara, "Formation of titanium oxide nanotube," Langmuir, vol. 14, pp. 3160-3163, Jun 91998.

[11]C. C. Tsai, J. N. Nian, and H. S. Teng, "Mesoporous nanotube aggregates obtained from hydrothermally treating $\mathrm{TiO}_{2}$ with $\mathrm{NaOH}, "$ Applied Surface Science, vol. 253, pp. 1898-1902, Dec 152006.

[12]L. S. Clesceri, A. D. Eaton, A. E. Greenberg, A. P. H. Association, A. W. W. Association, and W. E. Federation, Standard Methods for the Examination of Water and Wastewater: American Public Health Association, 1998.

[13]C.-C. Tsai and H. Teng, "Regulation of the Physical Characteristics of Titania Nanotube Aggregates Synthesized from Hydrothermal Treatment," Chemistry of Materials, vol. 16, pp. 4352-4358, 2004/11/01 2004.

[14] M. Zhang, Z. Jin, J. Zhang, X. Guo, J. Yang, W. Li, et al., "Effect of annealing temperature on morphology, structure and photocatalytic behavior of nanotubed $\mathrm{H}_{2} \mathrm{Ti}_{2} \mathrm{O}_{4}(\mathrm{OH})_{2}$," Journal of Molecular Catalysis A: Chemical, vol. 217, pp. 203-210, 8/3/ 2004.

[15]R. Yoshida, Y. Suzuki, and S. Yoshikawa, "Effects of synthetic conditions and heat-treatment on the structure of partially ion-exchanged titanate nanotubes," Materials Chemistry and Physics, vol. 91, pp. 409-416, 6/15/ 2005.

[16]E. Morgado Jr, M. A. S. de Abreu, O. R. C. Pravia, B. A. Marinkovic, P. M. Jardim, F. C. Rizzo, et al., "A study on the structure and thermal stability of titanate nanotubes as a function of sodium content," Solid State Sciences, vol. 8, pp. 888-900, 8// 2006.

[17]N. Wang, H. Lin, J. Li, X. Yang, B. Chi, and C. Lin, "Effect of annealing temperature on phase transition and optical property of titanate nanotubes prepared by ion exchange approach," Journal of Alloys and Compounds, vol. 424, pp. 311-314, 11/9/ 2006.

[18]J. Yu, H. Yu, B. Cheng, and C. Trapalis, "Effects of calcination temperature on the microstructures and photocatalytic activity of titanate nanotubes," Journal of Molecular Catalysis A: Chemical, vol. 249, pp. 135-142, 4/18/ 2006

[19] C.-K. Lee, C.-C. Wang, M.-D. Lyu, L.-C. Juang, S.-S. Liu, and S.-H. Hung, "Effects of sodium content and calcination temperature on the morphology, structure and photocatalytic activity of nanotubular titanates," Journal of Colloid and Interface Science, vol. 316, pp. 562-569, 12/15/ 2007.

[20] M. Qamar, C. R. Yoon, H. J. Oh, N. H. Lee, K. Park, D. H. Kim, et al., "Preparation and photocatalytic activity of nanotubes obtained from titanium dioxide," Catalysis Today, vol. 131, pp. 3-14, 2/29/ 2008.

[21]C.-K. Lee, M.-D. Lyu, S.-S. Liu, and H.-C. Chen, "The synthetic parameters for the preparation of nanotubular titanate with highly photocatalytic activity," Journal of the Taiwan Institute of Chemical Engineers, vol. 40, pp. 463470, 7// 2009.

[22]R. A. Doong, C. W. Tsai, and C. I. Liao, "Coupled removal of bisphenol A and copper ion by titanate nanotubes fabricated at different calcination temperatures," Separation and Purification Technology, vol. 91, pp. 8188, May 32012.

[23]F. Jiang, S. Zheng, L. An, and H. Chen, "Effect of calcination temperature on the adsorption and photocatalytic activity of hydrothermally synthesized $\mathrm{TiO}_{2}$ nanotubes," Applied Surface Science, vol. 258, pp. 71887194, 7/1/ 2012.
[24]B. Poudel, W. Z. Wang, C. Dames, J. Y. Huang, S. Kunwar, D. Z. Wang, et al., "Formation of crystallized titania nanotubes and their transformation into nanowires," Nanotechnology, vol. 16, p. 1935, 2005.

[25]L. Q. Weng, S. H. Song, S. Hodgson, A. Baker, and J. Yu, "Synthesis and characterisation of nanotubular titanates and titania," Journal of the European Ceramic Society, vol. 26, pp. 1405-1409, // 2006.

[26]D. D. Vuong, D. T. N. Tram, P. Q. Pho, and N. D. Chien, "Hydrothermal Synthesis and Photocatalytic Properties of TiO2 Nanotubes," in Physics and Engineering of New Materials. vol. 127, D. Cat, A. Pucci, and K. Wandelt, Eds., ed: Springer Berlin Heidelberg, 2009, pp. 95-101.

[27] S. Sreekantan and L. C. Wei, "Study on the formation and photocatalytic activity of titanate nanotubes synthesized via hydrothermal method," Journal of Alloys and Compounds, vol. 490, pp. 436-442, 2/4/ 2010.

[28]H. Wang, S. Zhou, L. Xiao, Y. Wang, Y. Liu, and Z. Wu, "Titania nanotubes-A unique photocatalyst and adsorbent for elemental mercury removal," Catalysis Today, vol. 175, pp. 202-208, 10/25/ 2011.

Nguyen Thi Thuy received his $\mathrm{PhD}$ degree in Environmental Engineering from National Chiao Tung University, Taiwan, in 2016. She is a lecturer at HCMC University of Industry. Her study now focuses on environmental engineering.

Huynh Tuan Anh and Ngo Vinh An were graduated from Ho Chi Minh City University of Technology, VNU-HCM in 2017. They are now working for private companies.

Nguyen Nhat Huy received his $\mathrm{PhD}$ degree in Environmental Engineering from National Chiao Tung University, Taiwan, in 2015. He is a lecturer at Ho Chi Minh City University of Technology, VNU-HCM. His study now focuses on the application of nanomaterials for water treatment and air pollution control. 


\title{
Nghiên cứu khử màu Procion 032 Carmine Red sử dụng xúc tác quang Titania dạng ống nano
}

\author{
Nguyễn Thị Thủy, Huỳnh Tuấn Anh, Ngô Vĩnh An, Nguyễn Nhật Huy
}

Tóm tắt— Trong nghiên cứu này, chúng tôi lần đầu tiên công bố về việc khử màu Procion 032 Carmine Red (PC032) sử dụng vật liệu xúc tác quang TNTs (titanate nanotubes). Vật liệu TNTs được tổng hợp bằng phương pháp kiềm hóa thủy nhiệt sử dụng $\mathrm{TiO}_{2}$ dạng bột làm tiền chất. Vật liệu TNTs thu được sau đó được nung ở các nhiệt độ khác nhau từ 100 đến $700^{\circ} \mathrm{C}$. Các đặc trưng vật liệu được phân tích bằng phương pháp hiển vi điện tử truyền qua (TEM), phương pháp đo vật liệu xốp Brunauer-Emmett-Teller (BET), và phương pháp nhiễu xạ tia $\mathrm{X}$ (XRD). Các thí nghiệm khử màu PC032 được tiến hành dưới điều kiện chiếu sáng tia cực tím (UV) trong một thiết bị phản ứng từng mẻ mà trong đó vật liệu TNTs được giữ lơ lững trong nước nhờ khuấy trộn. Kết quả thí nghiệm cho thấy nhiệt độ nung ảnh hưởng rất lớn đến tính chất của vật liệu và hoạt tính quang xúc tác của nó. Khi tăng nhiệt độ nung vật liệu thì diện tích bề mặt riêng giảm trong khi độ tinh thể hóa tăng lên. Trong thí nghiệm khử màu quang xúc tác $\mathrm{PC} 032$, vật liệu TNTs nung ở $600^{\circ} \mathrm{C}$ (T-600) Có hiệu quả xử lý cao nhất, đạt gần $100 \%$ sau 60 phút tiến hành thí nghiệm. Thí nghiệm độ bền xúc tác cho thấy vật liệu T-600 vẫn cho hiệu quả xử lý tương đối ổn định sau 10 lần tái sử dụng. Hơn nữa, vật liệu T-600 cũng hiệu quả cho việc khử màu một số loại thuốc nhuộm công nghiệp khác và là một loại vật liệu rất hứa hẹn cho xử lý nước thải bậc cao trong ngành dệt nhuộm.

Tù̀ khóa-TNTs, Procion 032 Carmine Red, thủy nhiệt, nước thải dệt nhuộm, xử lý nước thải quang xúc tác 